\title{
State, citizenship, and common good: British idealists' influence on social philosophy and planning culture
}

Luigi Mazza

\begin{abstract}
This paper is part of an investigation of the relationship between planning and citizenship, and considers the contribution of British Idealists because it advances of almost a century the contribution given by Marshall in the '50s of the last century, which is usually the starting point of contemporary debates on citizenship. British Idealists takes on the not easy task of reconciling a liberal and lay vision with the need of an ethical base of the State. Idealists' contributions change the role given to the State by the tradition of the liberal political thought and establish key issues to contemporary reflections on citizenship and social State. From the planning practice point of view Idealists' contribution is especially interesting because it is based on the notions of citizenship and common good, keywords for planning and, unsurprisingly, Idealists' influence on planning culture, is mostly on Geddes. Despite a lay political culture has difficulties in sharing their religious approach, it must be acknowledged that Idealists face issues and problems which were and continue to be relevant for the contemporary debate.
\end{abstract}

\section{Background}

Many years ago I understood that land use planning actions have effects on citizenship. Although these effects are often involuntary or unaware, they are important because they change social and political citizenship of the people living in the planned area. Due to these effects citizenship might become an evaluation standard of land use planning actions.

This paper is part of an investigation of the relationship between planning and citizenship, and considers the contribution of British Idealists because it advances of almost a century the contribution given by Marshall in the '50s of the last century, which is usually the starting point of contemporary debates on citizenship.

In the second half of the nineteenth century, the years of Cerdà and Geddes, a strong cultural and political influence was exerted by the Idealist school, a small group of philosophers based in Oxford and Scotland ${ }^{\mathrm{a}}$. The Idealist contribution is useful for understanding problems and ideas of that period and identifying some authors who influenced planning culture, in particular the, not always understandable, Geddes' writings ${ }^{\mathrm{b}}$.
British Idealists takes on the not easy task of reconciling a liberal and lay vision with the need of an ethical base of the State. Idealists' contributions change the role given to the State by the tradition of the liberal political thought and establish key issues to contemporary reflections on citizenship and social State.

According to Vincent and Plant - to whom we particularly refer in this paper-Idealists see the role of the State not merely "as a set of instrumentalities for securing material welfare, but as the focus of a sense of community and citizenship, an institution in which a good common to all classes and recognizable by all interest groups could be articulated. The purpose of the State was to promote the good life of its citizens and to develop the moral nature of man" . Idealists redesign the liberal political philosophy and are crucial for the development of social democracy and the creation of $\mathrm{New}$ Liberalism, whose roots are in the 1880 s. Idealist political theory is a key to understand the internal contradictions of the State, caused by the secularization process; contradictions which have main consequences on planning processes, on the opportunities for designing a planning system and getting it working properly. 
From the planning practice point of view Idealists' contribution is especially interesting because it is based on the notions of citizenship and common good, keywords for planning and, unsurprisingly, Idealists' influence on planning culture, is mostly on Geddes ${ }^{\mathrm{d}}$.

Despite a lay political culture has difficulties in sharing their religious approach, it must be acknowledged that Idealists face issues and problems which were and continue to be relevant for the contemporary debate.

\section{An important philosophical school}

During the middle of the nineteenth century, notwithstanding a political context less fragmented than the present one, supported by a strong feeling of the nation and guaranteed by a national and imperial culture, British society had to face problems and anxieties produced by the social and economic transformations linked to the industrial revolution. In a condition both of strength and uncertainty, the problem of finding an agreement between a liberal and secular vision and the need of an ethical basis for the State is the core of British Idealists reflection. Idealists' philosophical school begin to establish its roots in Scotland and Oxford and rapidly become the dominant philosophy until the turn of the twentieth century.

Despite internal differences of opinion, British Idealists exert a strong influence on the political debate which in those years is beginning to discuss the basic features of the welfare State. Idealists directly address many of the anxieties of the time, and provide a coherent and attractive alternative to conventional utilitarian and naturalistic thought. The contributions given by the British Idealists change the role assigned to the State from the tradition of political liberal thought and constitute the starting point of the contemporary reflection on citizenship and welfare ${ }^{\mathrm{e}}$.

Moreover Idealists' political theory allows a better understanding of the State's internal contradiction produced by the secularization process; a contradiction which has heavy consequences for the planning practices, in particular for the design and effectiveness of a planning system. From our point of view their contribution is interesting because its core is formed by the notions of citizenship and common good within the perspective of the welfare State. These are key words for planning and unsurprisingly it is possible to recognize Idealists influence on the planning culture, in particular on Patrick Geddes .

Finally, Idealists give a more correct and complete perspective to the contemporary debate on citizenship, their contribution moves back of almost a century the beginning of the debate, usually considered proceeding from the contribution given by Marshall in the 1950s.

In conclusion, their religious approach and the solutions they offer are hardly shared by a secular political culture, characterized by a diffused moral pluralism.
However, Idealists consider problems which continue to maintain their relevance for the current debates.

\section{A metaphysical theory of politics}

We must not be biased by the label of idealism, central to Idealists' theoretical proposal is the human experience, an experience which is considered continuously penetrated and enlightened by the divinity and guided by ideals which animate it and give it a concrete form. T. H. Green, generally considered the pivotal figure of the school, writes: "Not the admission of an ideal world of guess and aspiration alongside of the empirical, but the recognition of the empirical itself as an ideal ... that only valid idealism which trusts not to a guess about what is beyond experience, but an analysis of what is within it" ${ }^{\prime \prime}$. And within it Green perceives the deity who works unseen behind what he calls "the outer world"h, and "pours the truth and love which transforms man's capabilities into actualities". Green thinks that the element in which lies the nerve of all progress "is the presence and everlasting vitality of ideals. ... To frame ideals Green believes to be of the essence of man's nature"j. Green finds the ideal in the experience, and recognizes it as more real than any or all of the particular experiences in which he finds it.

This religious approach is a key aspect of the metaphysical foundation of their political theory and can be properly understood if we consider that in those years principles permeating a true secular Liberalism were nothing else but the application to public affairs of a religious spirit, "Religion became, for many, virtually synonymous of civic service and citizenship. ... Morality was, therefore, central to the economic and political life of man"k. Religion was view by the Idealists, in general, as an inextricable part of the process of self-realisation. The divine and the human constitute the inseparable spiritual unity of the world .

Idealists locate their way of understanding a collective action, the common good and freedom, in a metaphysical theory which claimed to state, in a more rational form: "the essence of the Christianity, and to do this in a way which largely by-passed the historical basis of that religion - a basis which was being increasingly contested during the second half of the nineteenth century. The wedding together of social and political theory with a powerful defence of Christianity, which at the same time drew upon but transformed some of the sources of contemporary doubt, gave to Idealism a force which it might not otherwise have had"m. The design of this wedding was eased by the conviction of many Idealists that a Christian moral consciousness was already implicit and immanent in the minds of citizens and therefore it was just necessary to give it a secularized form of politics and moral theory ${ }^{\mathrm{n}}$. 


\section{A new concept of citizenship}

Vincent and Plant open their book on the British Idealists quoting MacIntyre who argues that Green "tried to inaugurate a new concept of citizenship which would link men of different social classes. The concept was based upon the notion that there was a good common to members of all classes, a goal the existence of which could be made visible in actual measures of educational reform and social welfare" ${ }^{\text {. }}$.

The new concept of citizenship is based on a concept of freedom which marks the New Liberalism. A positive freedom linked to the idea of self-realization, to the actualization and development of one's possible self. A freedom which consists of motivated actions, that is to say those actions which involve the transformation of impulses to serve those ends and purposes with which one has identified oneself. An idea of freedom as being the ability and power to make the best of one's self and as such being part of divine disclosure in the human per$\operatorname{son}^{\mathrm{P}}$. An idea of freedom as social and overall moral emancipation, Green writes: "We who were reformers from the beginning always said that the enfranchisement of the people was an end in itself. We said, and we were very much derided for saying so, that only citizenship makes the moral man; that only citizenship gives that self respect which is the true basis of respect for others, and without which there is no lasting social order or real morality. (emphasis added) ${ }^{\mathrm{q}}$. With few exceptions, for many British Idealists, philosophy is integrally related to practical life and should be directed to improve the condition of society.

Green and Bradley both associated morality with selfrealisation, which unlike pleasure, was the object of moral action. Bradley, for example, argues that self-realisation is a moral duty. We have a duty to realise our best self. Selfrealisation is thus directly associated with the common good. The common good is inconceivable apart from membership in a society, and the self that is to be realised through moral activity "determined, characterised, made what it is by relations to others"s. According to Green society is "the condition of the development of our personality".

Citizenship is secured through a standard of property and security. Its development is guaranteed by the opportunities of rational community life $\mathrm{e}^{\mathrm{t}}$.

Freedom and individuality are for most of Idealists inextricably linked to citizenship, that is, to the idea of self-development within a civilised society. Freedom is not, therefore associated with the absence of constraints, but, rather with acting in accordance with the higher good, or general will of the community. Freedom is associated with choice, yet to act rationally is to make choices in conformity with one's highest interests. The existence of poverty, social deprivation, and appalling conditions of work are quite simply incompatible with these ideals. Economics has to be subordinate to morality, and the State as a sustainer of the moral community has to take an active role providing the conditions in which this transformations can take place. Rights thus always belong to individuals as members of a community. They are justifiable claims recognised as rational and necessary for the common good ${ }^{\mathrm{u}}$. There is a considerable ambiguity in Green's notion of common good. The ambiguity arises through the conflicting ideas that it is impossible to realize the common good in a competitive society, and that competition is necessary ${ }^{\mathrm{v}}$.

A social philosophy which places conceptions such citizenship and the common good at the very centre of its understanding of society has to be preoccupied with those factors which weaken the integration of citizens into society. One of the major factors making for a lack of integration in modern society is poverty. The problem with poverty is how to alleviate it in a manner consistent with the principles of civil society ${ }^{\mathrm{w}}$. Two responses at the problem: an individualised one which looks at the responsibility of the individual for his own deprivation and sees ways to enable him to overcome poverty through his own efforts. The other response is community-orientated: the settlement movement $t^{x}$ seeks to influence and permeate the way of life of a local community so that the community can help itself to identify its problems and seek solutions to them ${ }^{\mathrm{y}}$.

Citizenship is understood not just as a legal status or habitual rule following, but an active reflective moral engagement. Green's arguments on citizenship show the deep-rooted metaphysical themes implicit within our political understanding and the practices of citizenship. He tries to show us the forms of thought which accompany such practices as citizenship. In this sense citizenship is unavoidably both political and metaphysical. Morality and citizenship are essentially training in selfdevelopment, but without any really detailed discussion of how they would moralize the market ${ }^{\mathrm{z}}$. Geddes has a similar belief on morality, while about the market he on one hand shares Ruskin's argument, on the other tries to develop his own without properly develop it.

In conclusion, an idea of citizenship which looks at men's abilities, to status and equality of opportunity in a competitive society. The question remains though, whether equality of citizenship can be maintained with inequality of income, and further, can social rights to citizenship exist within the nexus of a capitalistic market society? ${ }^{\text {aa }}$

\section{Citizenship, common good and rights}

Citizenship, understood in a metaphysical framework, is the central category of Green's political philosophy. Citizenship implies a consciousness of the moral ends of 
human life as embodied within the institutional structure of the State; in other words, a consciousness of the common good $^{\text {ab }}$.

The common good is recognized as the possibility of better developing ones skills, and allowing others to do likewise and thus is in some circular way. A notion of common good in which different groups and different interests can identify and, as such, should be the link between the different social classes. The common good does not presuppose identity of interests. Separation of interests in the State represents one aspect of its reality. For Green the common good exists in a partial sense. While competition, hardship and class division remain, the common good remains essentially a counsel of perfection, potentially present as the purpose of the perfect State. The common good is thus present, for Green, in the very fact of having a State and a community, in the possibility of making the best of oneself in one's social function and seeking for the same for others ${ }^{\mathrm{ac}}$.

Green does not allow there to be a fundamental dichotomy between personal and public good, not because he is a collectivist as such, but rather because he sees a non-contingent relationship between persons and society so that an individual's possible self has an intrinsic social dimension. This position and the arguments which he uses to support it is crucial for his overall political philosophy and for his conception of Liberalism. The argument seeks to establish the metaphysical basis of the view that between classes, hierarchies and groups in a society there is still a common good which all men share, whatever their differences in natural powers and social circumstances, and which is the basis for community lift, linking all persons in society into one harmonious whole ${ }^{\text {ad }}$. Green concludes that society is 'the condition of the development of our personality'.

The mutual recognition of persons and their self realization do not require any fundamental change in the present distribution of goods in society although it requires certain kinds of social services to be provided which are not in Green's time widely thought to be necessary, those which bring a relief from the pressure of animal wants. Such a supply of the means of living allows room for the consideration of the ends of living. But this provision is not thought to be such as to fundamentally alter property relationships in society. Mutual respect and citizenship do not require a radical revision of inequalities.

Thus, the concept of citizenship represents a coordination and subordination of individual actions towards some common good. It also represents a respect and realization of the moral worth of each person. Citizenship is a prerequisite of true democracy based on respect.

To Idealists like Green, citizenship implies a noble purpose. Citizenship is active and orientated to community life. Citizenship endorses the unity of the conscience of man and the public laws, of reason and authority, and of spirit and the flesh. The concept of citizenship has a remoteness, and somewhat lofty ring to it, even in the 1900s. It presupposed an extensive educational background and awareness, which is in itself a severe drawback $^{\mathrm{ae}}$. It is clear that any theory of constructive citizenship is going to have something to say about education ${ }^{\text {af }}$.

Citizenship is considered awareness of the common good and purpose of human life embedded in institutional forms of the State, and as such, is an active practice, oriented to the community. For the Idealists citizenship is not a protective and largely negative idea, but "a historical, optimistic, promotional and ethical device, designed to enhance and develop positive freedom. It is viewed essentially as the moral achievement of a civilised community"ag.

Rights are seen as beneficial features which arose only in a social situation. A right is seen as dependent on the common good, in the sense that it is a power to act for one's own good, secured to the individual by the community, "on the supposition that its exercise contributes to the good of the community ${ }^{\text {"ah }}$. Rights, like laws and institutions, are bound up with the realizations of individuals and their needs. "This foundation, in Green's view, means that an individual exercising rights is intrinsically, or involuntarily, recognizing the common good. The capacity for rights in individuals is a social phenomenon; it can be guided and moralized through such institutions of society as the family. ... unequal freedom of contract, unlicensed drink traffic, and insanitary homes, and going beyond Green's stipulations, bad wages and fluctuations and seasonal employment, could affect the individual's capacity for exercising rights. It was through rational citizenship that a man became free and served the common good"ai.

The moral capacity in each man is to Green "a consciousness on the part of the subject of the capacity that its realization is an end desirable in itself, and rights are the condition of realizing it ${ }^{\text {maj }}$. Thus, they are, in a sense, "the negative realization of power". They are not an arbitrary creation, neither are they antecedent to society, but are created in a social situation and need to be recognized by others in order to become rights. Green deals summarily with natural right. Rights apart from society are a contradiction. To ask why I accept rights prescribed in society, or in fact to the power of the State, would be like asking why I allow my life to be ruled by a complex of institutions without which I should literally have no life to call my own.

Rights are therefore defined by John MacCunn as "advantageous conditions of social well-being indispensable to the true development of the citizen, enjoyable by all members of the community, and which we are prepared 
to say that respect for them ought (in one way or another) to be enforced. The advantage of rights should be for MacCunn, the opportunities they bring ${ }^{\text {ak }}$.

The conception of citizenship becomes "a standard by which our life-whether in the family, in the urban or rural neighbourhood, in trade or industry, in the Church, or in the work of charity-may be, and must be, criticised if it is to be in the full sense human"al. Where to criticize is "to adjust a part to its due and harmonious relations with a whole."

Because of the social problems faced by Britain and of the political and philosophical debate in that decades, it not surprising that a great attention was focused on the need of overcoming "the wilderness of 'interests' which constitute the texture of modern society" and of finding any clue to a unity between our surroundings in which we are imprisoned from birth, and the life and well-being of our fellow-countrymen as a whole"m. Bosanquet's main preoccupation is to recover the unity principle "which at first sight, may appear to have deserted the modern world"an. Social fragmentation and the wilderness of particular interests seem to be the reasons for a new conception of the society and citizenship and a new role of the State.

\section{State and freedom}

As Green maintained in his famous lecture, 'Liberal Legislation and Freedom of Contract': "When we speak of freedom as something to be highly prized, we mean 'a positive power or capacity of doing or enjoying something worth doing". This enjoyment was something we experienced in common with others. Measurement of the progress of society was thus by the development and exercise of powers contributory to the common good. Happiness was only a by product of the moral imperative to pursue the selfdevelopment and to became a rational citizen ${ }^{\text {ao }}$.

Social institutions or legal practices, for Green, are justified only to the extent that they furthered the selfrealisation of individuals. The citizen is not simply a the passive recipient of rights, but rather an active selfrealising being. Green viewed all political concepts from this standpoint. Rights, obligations, property or freedom were devices to allow individuals to realise their powers and abilities.

This includes defence of the State in the name of freedom, as it is to ensure freedom from suffering, without which the moral life cannot be lived. Underlying the idea of citizenship is this new concept of freedom, a freedom based on power to do and to take part; the idea of citizenship that focuses on individual skills and equality of opportunity developed within a competitive society.

Positive freedom is identified with rational and moral action, a reconciliation of the objects of will and the objects of reason, that is willing the common good ${ }^{\mathrm{ap}}$.
By the 1890s and 1900s the State is beginning to be viewed as an integral part of economic and political life. The State is therefore a moral agent, with ideals and purposes which it formulated and pursued for the betterment of society as a whole. Within the idealist perspective, there is no separation between the State and its citizens; on the contrary, a good State and good citizens go hand in hand. According to Jones "The power of the good State empowers the citizen, and the power of the good citizen empowers the State" ${ }^{\text {aq }}$. The perfection and moral condition of a State is dependent upon the degree of citizenship in its membership. "Thus if the State provisionally represented the common purposes of individuals, it could be seen figuratively as a single individual being the representation of the common purposes of all men within it. Again, most of the Idealists identified true individuality, citizenship and self-development with freedom. Real freedom was not the absence of compulsion but the maximum of power for all members of society to make the best of themselves" ${ }^{\text {mar }}$.

For all Idealists, "the State is comprised of numerous social organisms-the family, class, clan, church and city-and each individual inevitably belongs to multiple groupings and associations. ... The State for the Idealists is therefore not only the apparatus of governance, but is also inclusive of the whole social organism. ... By associating sovereignty with the State, Idealists posited a general will which was the 'real will' of the community and of which the real will of each individual was a manifestation. Organised society is seen to embody an ideal of life, along with the will to pursue more elevated and rewarding ends than any single individual can attain on his or her own"as.

Nineteenth-century individualists often viewed society either as an aggregate of embodying separate atoms or an organism. The communitarian-inclined theories of the Idealists thus had to combat both utilitarianism individualism and the organic individualism of Herbert Spence and Leslie Stephen. Utilitarianism was one of the dominant vocabularies and Bradley and Green, amongst others, criticised it for failing to account for moral and political activity. Morality, for the Idealists, was social in character. Acting morally entailed a reciprocal concern for others, and not merely a desire to achieve a private State of mind like happiness or utility" ${ }^{\text {"at }}$. For the Idealists, individualists neglected the spiritual nature of the social organism, which is neither mechanical nor biological, but instead depends upon the relation in which each person stands with every other. "The sinews and ligaments of society are the moral ideas and personal relations, without which a society would be a mere aggregation." The theory of the Idealists entailed a wide range of moral duties, responsibilities and obligations. These moral notions were conceived of as binding on the State 
and the individual. The State was ultimately a moral institution which aimed at a common good ${ }^{\text {au }}$.

The moral function of law, rights and the State was the fundamental concern of Green's political philosophy. The aim of the law was to provide conditions for the development of man's capacities and powers towards a moral end of self-realization. The capacity of institutions to achieve this end was the criterion of their moral development and progress. Civic institutions were therefore, in a sense, the outward expression of morality. Thus the State as the repository of man's idea of good, reflected the moral consciousness of all men ${ }^{\text {av }}$.

Intervention by the State has the duty to provide and maintain minimum conditions of life especially with regards to health, work and education, with the awareness that low wages and irregular employment limit individuals' capacity to exercise their rights. "Richtie saw the State as the most adequate representative of the general will in the community. For Bosanquet, it was the sustainer of the rights which underpinned any good life. Without the State the individual was nothing. This did not mean that the individual owed the State blind obedience. The State for the Idealists was only a moral absolute when acting for the common good. Green recognised that resistance, in certain circumstances, was absolutely necessary" ${ }^{\text {"aw }}$.

Jones, like many of his fellows Idealists, including Caird, distinguished between true and false socialism. True socialism was ethical and communitarian in nature and provided conditions for individual moral development. False socialism allowed no scope for individual freedom. For many of the civic-minded Idealists, it was the large cities, faced with the consequences of rapid industrial growth, that had to confront the issue of the extent to which the community should 'interfere', in order to meliorate the plight of the disadvantaged. The Idealists refused to accept that there was an absolute opposition between the individual and the State. The liberal socialist State could not make men moral, but, it could remove the obstacles to self-realisation ${ }^{\text {ax }}$.

It was in this light that the State was viewed by the Idealists as an institution embodying the mind and purpose of its members, not members or parts as in a machine, but living, independent, rational and organic members. The State was the most important institution, since it united all the range of voluntary and statutory associations and groups embodying more limited purposes within them ${ }^{\text {ay }}$.

\section{Conclusions}

Idealists defined a political theory which places a great emphasis upon the moral vocation of citizenship and the value of community organized around a common good. Views of citizenship, the individual and the State which connect political life with moral notions like human capacities, self-respect, interdependence and mutual obligation, and which see will and voluntary commitment at the basis of the State, are going to be classified as metaphysical $^{\text {az }}$. Unsurprisingly a liberal anarchist like James M. Buchanan wrote that Idealists' political philosophy "put up barriers against any realistic examination of politics." Certainly their religious approach cannot be understood and accepted by who pursues a secular vision of State and society, however a secular vision has to find a solution to the internal contradiction posed by the values' presuppositions. Idealism fulfilled a number of roles in societies that were experiencing the effects of rapid industrialisation, modernisation and secularisation. It acted as a counterbalance to the individualism of the more brash variants of utilitarianism, offering a philosophy that gave a much needed emphasis to social cohesiveness and to the closeness of the relation between individual and collective responsibility. Its emphasis on the importance of active social citizenship became an important theme in early twentieth-century politics and welfare theory. Against the conception of humanity in naturalistic theories of evolution, Idealists offered an elevated view of the relation between humanity and nature ${ }^{\text {ba }}$. The emphasis on the unity of nature and spirit, the comprehensive view of the world and inclusive view of the society, the prospection of a third way in between socialism and individualism are the main characters which suggest that Idealists had an influence on Geddes and his ideas on planning $^{\mathrm{bb}}$. Moreover their ideas of citizenship and of the relationships between the individual and the State are still issues for the current debates.

\section{Endnotes}

${ }^{a}$ British Idealism is represented by a small group of people, being T.H. Green (1836-1882) the pivotal figure and others including: Edward Craig (1835-1908), William Wallace (1843-1897), F.H. Bradley (1846-1924), Bernard Bosanquet (1848-1923), Richard Burdon Haldane (18501928), Henry Jones (1852-1922), David G. Ritchie (18561903), Robin G. Collingwood (1889-1943) e Michael Joseph Oakeshott (1901-1990).

${ }^{\mathrm{b}}$ This paper is moreover based on: Hay 1975; Henriques 1979; Plant et al. 1980; Vincent and Plant 1984; Vincent 1986 e 1987; Brown 1995; Boucher and Vincent 2000; Fraser 2003; nonchè a: Bosanquet 1895 e 1899; Helen Bosanquet 1899; MacCunn 1907; Beveridge 1936.

${ }^{\mathrm{c}}$ Vincent and Plant 1984, 2.

${ }^{\mathrm{d}}$ Mazza 2008, 2009.

'Vincent and Plant 1984; Vincent 1986; Boucher and Vincent 2000.

${ }^{f}$ Mazza 2008, 2009.

${ }^{g}$ Green, Works, I, 449. Quoted by MacCunn 1907, 218.

${ }^{\mathrm{h}}$ Even if with another intention Geddes uses the same term. 
iGreen, Works, III, 4. "Green's (and Hegel) argument, however, is that the Christian religion has introduced a principle of individualism and freedom which fragmented, particularly the unified civic world of the Greeks. This Greek civic world could never be fully recovered, although it could be integrated into something more developed. The recovery of an integrated community, which embodies all the key components of individual autonomy (introduced initially in the Christian perspective), is the central aim of Green and Hegel. ... The Reformation introduced a new positive form of autonomous consciousness, present in the liberal Protestant citizen, which is, in fact, at the very metaphysical heart of both liberalism and the Christian perspective." Boucher and Vincent 2000, 35.

${ }^{j}$ MacCunn 1907, 225.

${ }^{\mathrm{k}}$ Herbert Samuel (1902) quoted by Vincent and Plant 1984, 54-55.

${ }^{\mathrm{l}}$ Boucher and Vincent 2000, 9.

${ }^{m}$ Vincent and Plant 1984, 6.

${ }^{\mathrm{n}}$ Ibid., 182-183.

${ }^{\circ}$ MacIntyre 1972.

PVincent and Plant 1984, 21.

${ }^{\mathrm{q}}$ Green quoted by Vincent and Plant 1984, 1.

${ }^{\mathrm{r}}$ Boucher and Vincent 2000, 10. Henry Jones, for example, thought that the most important work for the philosopher was to improve the condition of ordinary working people.

sIbid., 11.

${ }^{\mathrm{t}}$ Vincent and Plant 1984, 86.

uBoucher and Vincent 2000, 12.

${ }^{\mathrm{v}}$ Vincent and Plant 1984, 67.

${ }^{\mathrm{w}}$ Vincent and Plant 1984, 94. How can a collective answer to poverty be produced in a social system marked by a strong sense of individualism? Hegel regarded the problem as insoluble and saw poverty as the main 'contradiction' of modern society.

${ }^{\mathrm{x}}$ Il settlement movement was established in London and Oxford in the ' 80 s of the nineteenth hundred century. Well-off university students share settlement houses with poor people and help them to improve their condition and their education.

${ }^{\mathrm{y}}$ Vincent and Plant 1984, 95.

${ }^{\mathrm{z}}$ Ibid., 33.

${ }^{\text {aa } I \text { lbid., } 82 .}$

${ }^{\mathrm{ab}}$ Boucher and Vincent 2000, 29.

${ }^{\text {ac } V i n c e n t ~ a n d ~ P l a n t ~ 1984, ~ 29-30 . ~}$

ad Ibid., 22.

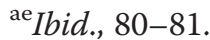

${ }^{\text {af }}$ Vincent and Plant 1984, 100.

${ }^{\mathrm{ag}}$ Boucher and Vincent 2000, 31.

${ }^{\text {ah }}$ Green, Collected Works II, 513; citato da Vincent and Plant 1984, 67.

${ }^{\text {ai } V i n c e n t ~ a n d ~ P l a n t ~ 1984, ~} 67$.

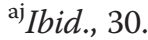

${ }^{\text {ak}}$ Quoted by Vincent and Plant 1984, 30.

${ }^{\text {al }}$ Bosanquet 1895, 12-13.

am Ibid., 14.

${ }^{\text {an Ibid., } 27 .}$

${ }^{\text {ao }}$ Vincent and Plant 1984, 70.

${ }^{\text {ap }}$ Boucher and Vincent 2000, 29.

${ }^{\text {aq Jones 1920, } 89 .}$.

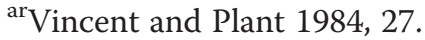

${ }^{\text {as }}$ Boucher and Vincent 2000, 10.

${ }^{\text {at } I \text { Ibid., } 11 .}$

${ }^{\mathrm{au}}$ Vincent and Plant 1984, 34.

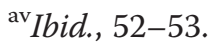

${ }^{\mathrm{aw}}$ Boucher and Vincent 2000, 12.

${ }^{\mathrm{ax}}$ Ibid., 13.

ay Vincent and Plant 1984, 29.

${ }^{\text {az Ibid., } 163 .}$

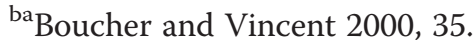

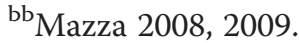

Competing interests

The author declare that he has no competing interests.

Received: 31 October 2013 Accepted: 28 March 2014

Published: 16 May 2014

\section{References}

Beveridge WH (1936) Planning under Socialism, and other addresses. Longmans, Green and Co., London

Bosanquet B (ed) (1895) Aspects of the Social Problem. MacMillan \& Co., London Bosanquet B (1899) The Philosophical Theory of the State. Macmillan, London Boucher D, Vincent A (2000) British Idealism and Political Theory. Edinburgh University Press, Edinburgh

Brown J (1995) The British Welfare State. A Critical History. Blackwell, Oxford

Fraser D (2003) The Evolution of the British Welfare State. A History of Social Policy since the Industrial Revolution. Palgrave Macmillan, Houndmills

Hay JR (1975) The Origins of Liberal Welfare. Macmillan, London

Henriques URQ (1979) Before the Welafare State. Social administration in early industrial Britain. Longman, London

Jones H (1920) The Principles of Citizenship. Macmillan, London

MacCunn G (1907) Six Radical Thinkers. Bentham, J.S. Mill, Cobden, Carlyle, Mazzini, Green, idealism. Edward Arnold, London

Maclntyre A (1972) Secularization and Moral Change. Oxford University Press, Oxford

Mazza L (2008) Geddes 'politico': vision, survey, citizenship. Territorio 45:91-98

Mazza L (2009) Riformatori morali e meccanici. Cittadinanza e controllo spaziale tra ottocento e novecento. In: Aa V (ed) Le frontiere della geografia. Testi, dialoghi e racconti per Giuseppe Dematteis. Utet, Novara, pp 293-310

Plant R, Lesser H, Peter T-G (1980) Political philosophy and social welfare. Essay on the normative basis of social provision. Routledge \& Kegan Paul, London

Samuel H (1902) Liberalism. Grant Richards, London

Vincent A (1986) The philosophy of T.H. Green. Paradigm, Gateshead

Vincent A (1987) Theories of the state. Blackwell, Oxford

Vincent A, Plant R (1984) Philosophy, Politics and Citizenship. The Life and Thought of the British Idealist. Blackwell, Oxford

doi:10.1186/2195-2701-1-6

Cite this article as: Mazza: State, citizenship, and common good: British idealists' influence on social philosophy and planning culture. City, Territory and Architecture 2014 1:6. 